\author{
Monika Kapusta*
}

\title{
INSTYTUCJA WYDALENIA ZE SŁUŻBY W POLICJI JAKO KONSEKWENCJA KARY DYSCYPLINARNEJ - WYBRANE ZAGADNIENIA
}

\begin{abstract}
Streszczenie. Celem niniejszego opracowania jest przybliżenie instytucji wydalenia ze służby w Policji, przy czym rozważania dotyczące tego zagadnienia zostały ograniczone do ściśle wybranych i opisanych zagadnień. W tekście zarysowano przebieg postępowania dyscyplinarnego w Policji. Omówiona została istota kary dyscyplinarnej wydalenia ze służby. Podano przykłady zachowań uzasadniających zastosowanie tej kary. Zwrócono również uwagę na konsekwencje wydalenia ze służby w Policji.

Słowa kluczowe: wydalenie ze służby w Policji, kara dyscyplinarna, postępowanie dyscyplinarne, przewinienie dyscyplinarne, zwolnienie ze służby, konsekwencje wydalenia ze służby.
\end{abstract}

\section{WPROWADZENIE}

W art. 1 ust. 1 ustawy z dnia 6 kwietnia 1990 r. o Policji (tekst jedn. Dz. U. 2015, poz. 355 ze zm.) (dalej: ustawa o Policji) mianem Policji określono umundurowaną i uzbrojoną formację służącą społeczeństwu i przeznaczoną do ochrony bezpieczeństwa ludzi oraz do utrzymywania bezpieczeństwa i porządku publicznego. Biorąc pod uwagę charakter i otwarty katalog powierzonych jej zadań ${ }^{1}$, nie ulega wątpliwości, że formacja ta pełni szczególną funkcję w systemie podmiotów związanych z zapewnianiem wskazanego powyżej bezpieczeństwa oraz porządku publicznego. To powoduje, co potwierdza orzecznictwo sądów administracyjnych, że Policja wyposażona jest W wiele środków wspartych władztwem, nierzadko o dużym stopniu dolegliwości dla jednostki (wyrok WSA w Warszawie z 14 sierpnia 2008 r.). Z licznych nowelizacji ustawy o Policji można wnioskować, że zmiany tej ustawy ukierunkowane są na coraz szerszy zakres ingerencji Policji, w tym w wolności i prawa człowieka. Ingerencja ta musi być dokonana na podstawie i w granicach ustaw. Specyfika działań tej formacji i groźba naruszenia wymogów prawnych rodzą konieczność objęcia funkcjonariuszy Policji rozbudowaną odpowiedzialnością. Jednym z jej rodzajów jest odpowiedzialność dyscyplinarna. Jak wskazuje się w judykaturze, jest ona uzasadniana: społeczną

* Uniwersytet Łódzki, Wydział Prawa i Administracji, Katedra Prawa Administracyjnego i Nauki Administracji, monika.kapusta.lodz@gmail.com.

${ }^{1} \mathrm{~W}$ tym w szczególności wymienionych w art. 1 ust. 2 ustawy o Policji. 
rolą tej formacji, charakterem powierzonych jej zadań i kompetencji oraz publicznym zaufaniem i przeciwdziałaniem zachowaniom mogącym pozbawić ją wiarygodności w oczach opinii publicznej (tamże). Wykonywanie obowiązków służbowych przez policjanta wymaga nie tylko przestrzegania prawa i dyscypliny służbowej, ale także zasad etyki zawodowej, do których należy zaliczyć szczególną staranność w wykonywaniu obowiązków (wyrok NSA z 19 stycznia 2007 r.). Trybunał Konstytucyjny stanął na stanowisku, że charakter służby publicznej służb mundurowych daje możliwość odmiennego i bardziej rygorystycznego - niż w przypadku innych zawodów i funkcji - kształtowania statusu służbowego m.in. w zakresie jego utraty (wyrok TK z 2 września 2008 r.). Pozbawienie statusu funkcjonariusza Policji może być m.in. następstwem potwierdzenia popełnienia przewinienia dyscyplinarnego.

\section{POSTĘPOWANIE DYSCYPLINARNE W POLICJI}

Zdaniem T. Kuczyńskiego odpowiedzialność dyscyplinarna, zwana w przeszłości służbową, stanowi jedną z instytucji charakteryzujących naturę pracowniczych i niepracowniczych stosunków służbowych (Kuczyński 2012, 24-25). W art. 132 ust. 1 ustawy o Policji stwierdzono, że policjant odpowiada dyscyplinarnie za popełnienie przewinienia dyscyplinarnego polegającego na naruszeniu dyscypliny służbowej lub nieprzestrzeganiu zasad etyki zawodowej. Naruszenie dyscypliny służbowej zostało zdefiniowane w art. 132 ust. 2 ustawy o Policji jako czyn policjanta polegający na zawinionym przekroczeniu uprawnień lub niewykonaniu obowiązków wynikających z przepisów prawa lub rozkazów i poleceń wydawanych przez przełożonych uprawnionych na podstawie tych przepisów. Co prawda ustawodawca zawarł w art. 132 ust. 3 ustawy o Policji przykładowy katalog naruszeń dyscypliny służbowej, jednakże nie jest on katalogiem wyczerpującym. W przypadku nieprzestrzegania zasad etyki zawodowej - w ustawie nie wskazano przykładowych zachowań. Przydatne są w tej sytuacji unormowania zawarte w załączniku do zarządzenia nr 805 Komendanta Głównego Policji z 31.12.2003 r. (Dz. Urz. KGP 2004, Nr 1, poz. 3): „Zasady etyki zawodowej policjanta". Są one zbiorem ogólnych norm etycznych, które uwzględniają specyfikę zawodu policjanta. W literaturze przyjmuje się, że jeśli nie zachodzi funkcjonalny związek z wykonywaniem zawodu, funkcjonariusz powinien kierować się powszechnie przyjmowanymi normami etycznymi, a jego zachowanie nie powoduje odpowiedzialności dyscyplinarnej (Baj, Bober 2013, 6).

Fakt popełnienia przewinienia dyscyplinarnego przez funkcjonariusza Policji musi zostać stwierdzony w postępowaniu dyscyplinarnym ${ }^{2}$. Jeżeli zachodzi uzasadnione przypuszczenie popełnienia przez policjanta przewinienia

${ }^{2} \mathrm{Na}$ marginesie stwierdzić należy, że mimo istnienia znaczących odrębności między postępowaniem karnym a dyscyplinarnym w art. 135p ustawy o Policji dopuszczono możliwość odpowiedniego stosowania k.p.k. w zakresie w nim wskazanym. 
dyscyplinarnego, to przełożony dyscyplinarny $\left.{ }^{3}: 1\right)$ wszczyna postępowanie dyscyplinarne: a) z własnej inicjatywy, b) na wniosek bezpośredniego przełożonego policjanta, c) na polecenie wyższego przełożonego, d) na żądanie sądu lub prokuratora; 2) może wszcząć postępowanie dyscyplinarne na wniosek pokrzywdzonego (art. 134i ust. 1 ustawy o Policji). Po wszczęciu postępowania - z uwagi na zaangażowanie jednoosobowych organów bywa ono nazywane gabinetowym (Maj 2008, 17) - jego prowadzenie kontynuowane jest przez rzecznika dyscyplinarnego. Podejmuje on wszelkie niezbędne czynności mające na celu ustalenie okoliczności faktycznych sprawy ${ }^{4}$. Zebrany w postępowaniu materiał dowodowy staje się podstawą do wydania przez przełożonego dyscyplinarnego orzeczenia o: uniewinnieniu albo odstapieniu od ukarania, albo ukaraniu, albo umorzeniu postępowania. Decyzja o ukaraniu oznacza konieczność wyboru jednej z kar wymienionych w art. 134 ustawy o Policji, tj.: nagany; zakazu opuszczania wyznaczonego miejsca przebywania; ostrzeżenia o niepełnej przydatności do służby na zajmowanym stanowisku; wyznaczenia na niższe stanowisko służbowe; obniżenia stopnia; wydalenia ze służby. Katalog wymienionych wyżej kar dyscyplinarnych wprowadzono przepisami ustawy z 29.10.2003 r. zmieniającej ustawę o Policji (Dz. U. Nr 192, poz. 1873). Ustawodawca ograniczył w niej liczbę kar dyscyplinarnych. Miało to na celu uczynienie ich katalogu bardziej czytelnym. Między innymi funkcjonujące wcześniej kary: nagany, surowej nagany i nagany z ostrzeżeniem, zastapiono jedną karą nagany. Z uzasadnienia projektu ustawy wynika, że wykonanie trzech odmiennie nazwanych kar nagany polegało na tym samym, tj. na wytknięciu ukaranemu jego niewłaściwego postępowania, przy czym różnica między tymi karami była praktycznie niewidocznas. Warto zauważyć, że mimo tak przedstawionej argumentacji chociażby w ustawie z 24 maja 2002 r. o Agencji Bezpieczeństwa Wewnętrznego i Agencji Wywiadu nadal znajduje się katalog kar dyscyplinarnych zbieżny z treścią katalogu z ustawy o Policji sprzed zmiany z 2003 r., co świadczy o pewnym braku konsekwencji ustawodawcy przy kształtowaniu kar w postępowaniach dyscyplinarnych (Giętkowski 2013, 272-280).

Dokonana w art. 134 ustawy o Policji gradacja kar oznacza stopniowanie dolegliwości środków, które mogą zostać zastosowane, przy czym prawodawca nie przyporządkował do konkretnych przewinień dyscyplinarnych określonych kar. Zostało to pozostawione uznaniu właściwego organu dyscyplinarnego. Zarówno w doktrynie, jak i orzecznictwie sądów administracyjnych przyjęto, że nie można utożsamiać uznaniowości z dowolnością w podejmowaniu decyzji (wyrok WSA w Warszawie z 17 stycznia 2006 r.; wyrok WSA w Warszawie z 26 lutego 2007 r.;

${ }^{3}$ Zgodnie z art. 32 ust. 1 ustawy o Policji jest nim odpowiednio: Komendant Główny Policji, Komendant Centralnego Biura Śledczego Policji, komendant wojewódzki, powiatowy (miejski) Policji bądź komendant szkoły policyjnej.

${ }^{4}$ Kwestię tę regulują szerzej art. 135e-135i ustawy o Policji.

${ }^{5}$ Por. uzasadnienie rządowego projektu ustawy o zmianie ustawy o Policji, druk nr 1815, http://orka.sejm.gov.pl/proc4.nsf/opisy/1815.htm [dostęp 24.4.2016]. 
wyrok WSA w Łodzi z 10 lutego 2015 r.). Kara musi być bowiem współmierna do popełnionego przewinienia, a zatem musi zostać wymierzona zgodnie, zwłaszcza, z zasadą proporcjonalności. W art. 134h ustawy o Policji wymieniono reguły, które powinny zostać zastosowane w postępowaniu dyscyplinarnym, w tym takie, które wpływają na złagodzenie i zaostrzenie wymiaru kary. Sądy administracyjne dokonując wykładni wskazanego przepisu, podnoszą w szczególności, że: „organ służbowy, podejmując decyzję o doborze jednej ze wskazanych w art. 134 ustawy o Policji kar dyscyplinarnych, powinien wziąć pod uwagę takie okoliczności, jak rodzaj naruszonych obowiązków (obowiązki służbowe sensu stricto, reguły postępowania wyznaczone pojęciem godności i powagi służby, reguły wykonywania zawodu określone normami zawodowej sztuki, etyki i deontologii), stopień tzn. intensywność ich naruszenia, stopień zagrożenia dla interesu służby, spowodowany naruszeniem obowiązków służbowych, dotychczasowy przebieg służby (stosunek do obowiązków), jak również element subiektywny, jakim jest stopień winy funkcjonariusza (wina umyślna w zamiarze bezpośrednim lub ewentualnym, wina nieumyślna w postaci nieostrożności - lekkomyślności). Wymiar kary powinien uwzględniać dyrektywy jej nakładania oraz okoliczności przemawiające tak na korzyść, jak i na niekorzyść obwinionego" (wyrok WSA we Wrocławiu z 27 października 2010 r.; wyrok WSA w Krakowie z 22 stycznia 2013 r.; wyrok WSA w Poznaniu z 9 października 2013 r.). Organ powinien dokonać wyważenia dóbr w taki sposób, by podjąć decyzję jak najbardziej optymalną. W orzecznictwie zwraca się uwagę na szeroki zakres uznania organów dyscyplinarnych w zakresie nakładania kar (m.in. wyrok WSA w Warszawie z 7 stycznia 2013 r.). Naczelny Sąd Administracyjny w wyroku z 23 stycznia 2014 r. odniósł się do zasad wymiaru kar dyscyplinarnych. Jego zdaniem: „na wymierzenie kary dyscyplinarnej funkcjonariuszowi Policji wpływ ma przede wszystkim waga czynu i stopień winy, zaś dobór kary adekwatnej do przewinienia dyscyplinarnego należy do sfery uznania organów dyscyplinarnych, gdyż ustawodawca nie określił, jakiemu przewinieniu odpowiada każda z sankcji wymienionych w art. 134 ustawy z 1990 r. o Policji. Sądowa kontrola orzeczenia dyscyplinarnego w części dotyczącej kary sprowadza się wyłącznie do oceny, czy organy przestrzegały reguł procedowania, w tym ustawowych dyrektyw wymiaru kar. Sąd nie może natomiast ingerować w uprawnienia zastrzeżone wyłącznie dla organu prowadzącego postępowanie dyscyplinarne i oceniać celowości czy słuszności zastosowanych przezeń sankcji”. Wydaje się, że kara wydalenia ze służby - z uwagi na swe daleko idące konsekwencje - ma być ostatecznością, ale z drugiej strony charakter służby w Policji i dbałość o jej społeczny wizerunek powodują nierzadko bardzo rygorystyczne podejście do przewinień dyscyplinarnych.

W przypadku zamiaru wymierzenia kary dyscyplinarnej wydalenia ze służby przełożony dyscyplinarny, przed wydaniem orzeczenia dyscyplinarnego, wzywa obwinionego do raportu w celu wysłuchania go, doręczając mu wcześniej sprawozdanie w terminie umożliwiającym zapoznanie się z nim przed raportem (art. 
135j ust. 9 ustawy o Policji). Obwinionemu policjantowi przysługuje prawo wniesienia odwołania w terminie 7 dni od dnia doręczenia orzeczenia ${ }^{6}$. Odwołanie jest składane do wyższego przełożonego dyscyplinarnego, za pośrednictwem przełożonego, który wydał orzeczenie w pierwszej instancji. W postępowaniu odwoławczym uwzględnia się stan faktyczny ustalony w postępowaniu dyscyplinarnym, ale dopuszczalne jest także przeprowadzenie uzupełniającego postępowania dowodowego (art. 1351 ust. 1 ustawy o Policji). W terminie 7 dni od wniesienia odwołania wyższy przełożony dyscyplinarny - co do zasady - może powołać komisję do zbadania zaskarżonego orzeczenia. Uprawnienie to, w przypadku zastosowania niektórych kar dyscyplinarnych (w tym: wydalenia ze służby), staje się obowiązkiem (art. 135m ust. 1 ustawy o Policji). Po przeprowadzeniu czynności komisja składa wyższemu przełożonemu dyscyplinarnemu sprawozdanie, a wyższy przełożony dyscyplinarny podejmuje decyzję odnośnie do zaskarżonego orzeczenia ${ }^{7}$. Decyzja wyższego przełożonego dyscyplinarnego przybiera postać: utrzymania w mocy zaskarżonego orzeczenia albo uchylenia go w całości lub w części i w tym zakresie uniewinnienia obwinionego, odstąpienia od ukarania, względnie wymierzenia innej kary, bądź przy uchyleniu tego orzeczenia - umorzenia postępowania dyscyplinarnego w pierwszej instancji, albo uchylenia w całości i przekazania sprawy do ponownego rozpatrzenia przez przełożonego dyscyplinarnego, gdy rozstrzygnięcie sprawy wymaga przeprowadzenia czynności dowodowych w całości lub w znacznej części. Decyzja ta może zostać następnie poddana kontroli sądów administracyjnych na skutek wniesienia skargi. Z możliwości kwestionowania nałożonej kary korzystają najczęściej osoby, wobec których zastosowano karę wydalenia ze służby.

\section{ISTOTA WYDALENIA ZE SŁUŻBY}

Artykuł 134f ustawy o Policji stanowi: „Kara wydalenia ze służby oznacza zwolnienie ze służby w Policji”, czyli de facto jest to pozbawienie osoby, która popełniła przewinienie dyscyplinarne, statusu policjanta (Czebotar 2015, 673674). W wyrokach sądów administracyjnych przyjmuje się, że ten rodzaj kary dyscyplinarnej winien zostać wymierzony w sytuacji, gdy waga czynu popełnionego przez funkcjonariusza wyklucza dalsze pełnienie przez niego służby w tej formacji (wyrok NSA z 16 listopada 2011 r.; Opaliński, Rogalski, Szustakiewicz 2015, 350). Zwolnienie to nie następuje samoczynnie, lecz na podstawie wydawanej obligatoryjnie decyzji. Wojewódzki Sąd Administracyjny w Krakowie

${ }^{6}$ Wyjątkiem jest orzeczenie Komendanta Głównego Policji, od którego nie przysługuje odwołanie, a wniosek o ponowne rozpatrzenie sprawy (por. art. 135k. ust. 4 ustawy o Policji). Można zauważyć, że koresponduje to z przepisami k.p.a.

${ }^{7}$ Możliwości przysługujące wyższemu przełożonemu dyscyplinarnemu w zakresie rozpoznania odwołania zostały wymienione w art. 135n ust. 4 ustawy o Policji. 
w wyroku z 15 stycznia 2009 r. stwierdził: „Właściwy organ Policji ma obowiązek zwolnienia policjanta ze służby, jeżeli wobec tego policjanta została orzeczona kara dyscyplinarna wydalenia ze służby i orzeczenie to ma walor decyzji prawomocnej". Po uprawomocnieniu się orzeczenia dyscyplinarnego właściwy organ Policji musi - na podstawie art. 41 ust. 1 pkt 3 ustawy o Policji - wydać tzw. decyzję kadrową (pojęcie to zostało użyte m.in. w przywołanym wyżej wyroku) o zwolnieniu ze służby. Stanowi ona akt wykonania kary dyscyplinarnej $\mathrm{i}$ - podobnie jak orzeczenie w przedmiocie zastosowania kary dyscyplinarnej wydalenia ze służby - może zostać zaskarżona w toku instancji, a także podlega kontroli sądów administracyjnych. Nie następuje to jednak w ramach kontroli postępowania dyscyplinarnego, a w ramach kontroli decyzji o zwolnieniu ze służby. Są to dwa odrębne postępowania. To drugie postępowanie jest specyficzne, bowiem postępowanie dyscyplinarne jest w nim badane przez sąd administracyjny, ale w zakresie sprowadzonym jedynie do właściwości organów, rodzaju zastosowanej kary i wykonalności orzeczenia (pogląd o odrębności postępowań dyscyplinarnego i w zakresie wydania decyzji o zwolnieniu ze służby w związku z wymierzeniem kary dyscyplinarnej wydalenia ze służby wyrażono m.in. w wyroku NSA (do 31.12.2003 r.) w Warszawie z 25 października 1999 r.).

\section{PRZYKŁADY ZACHOWAŃ UZASADNIAJĄCYCH WYDALENIE ZE SLUŻBY}

$\mathrm{Z}$ analizy orzecznictwa dotyczącego wskazanej tematyki wynika, że sądy administracyjne na ogół podtrzymują rozstrzygnięcia organów dyscyplinarnych. Wpływać może na to wiele rozmaitych czynników, w tym m.in. wąski zakres kontroli rozstrzygnięć dyscyplinarnych przez te sądy i - niejednokrotnie - poprawność proceduralna przeprowadzanych postępowań dyscyplinarnych.

W praktyce działania Policji, poddanej ocenie sądów administracyjnych, znaleźć można różne przykłady zachowań, których następstwem było zastosowanie kary wydalenia ze służby. Klasyfikacji w tym zakresie dokonuje m.in. sama Policja. W corocznie sporządzanych w Komendzie Głównej Policji: Zestawieniach prowadzonych i zakończonych postępowań dyscyplinarnych ${ }^{8}$ (dalej: Zestawienia) znaleźć można dane liczbowe zarówno dotyczące popełnionych przewinień, jak również różne podziały tych przewinień. W dalszej części opracowania odniosę się do kategorii przewinień dyscyplinarnych, wymienionych w Zestawieniach, których duża liczba świadczy o doniosłym charakterze dla analizowanego zagadnienia. Podanie przykładów przewinień, z uwagi na brak tego typu informacji w Zestawieniach, wymaga odwołania do judykatury.

\footnotetext{
${ }^{8}$ Materiały uzyskane na potrzeby badań naukowych z Komendy Głównej Policji.
} 
Wśród przewinień dyscyplinarnych skutkujących nałożeniem tego rodzaju kary warto wyodrębnić podgrupę czynów popełnionych pod wpływem alkoholu. Ustawodawca, w art. 134h ust. 2 pkt 1 ustawy o Policji, stan po użyciu alkoholu uznał za przesłankę zaostrzenia wymiaru kary dyscyplinarnej. Znamienne jest, że w Zestawieniach wydziela się wśród przewinień dyscyplinarnych: „przewinienia popełnione po alkoholu". W moim przekonaniu wymaga to podkreślenia, ponieważ żadne inne okoliczności wpływające na zaostrzenie wymiaru kary nie przełożyły się na wyselekcjonowanie podgrupy przewinień w Zestawieniach. Mając na uwadze powyższe, można dokonać podziału przewinień dyscyplinarnych na:

1) naruszenie dyscypliny służbowej lub norm etycznych dokonane w stanie po spożyciu alkoholu;

2) naruszenie dyscypliny służbowej lub norm etycznych dokonane w stanie trzeźwości.

Wśród przewinień dyscyplinarnych popełnionych po spożyciu alkoholu, zwrócenia uwagi wymagają w szczególności te polegające na:

a) stawieniu się do służby w stanie po użyciu alkoholu oraz spożywanie alkoholu w czasie służby albo $\mathrm{w}$ obiektach lub na terenach zajmowanych przez Policję;

b) podjęciu czynności zawodowych;

c) prowadzeniu pojazdu;

d) wulgarnym, obraźliwym zachowaniu, zakłócaniu spokoju (w tym ciszy nocnej).

Wyroki sądów administracyjnych potwierdzają wielorakie zachowania policjantów w obrębie kategorii: naruszenie dyscypliny służbowej lub norm etycznych w stanie po spożyciu alkoholu. Warto przytoczyć chociażby przykład, w którym funkcjonariusza uznano za winnego podjęcia czynności zawodowych w stanie po użyciu alkoholu oraz posiadania przy sobie w tym czasie służbowej broni palnej, za co została mu wymierzona kara dyscyplinarna w postaci wydalenia ze służby (wyrok WSA w Olsztynie z 16 marca 2004 r.). W tym miejscu warto zauważyć, że stawienie się do służby w stanie po użyciu alkoholu, w art. 132 ust. 3 pkt 6 ustawy o Policji, zostało określone jako przewinienie dyscyplinarne, wobec czego zachowanie takie należy poddać szczególnej krytyce, nawet jeśli funkcjonariusz nie wykona następnie żadnych czynności służbowych. Dodatkowo w przytoczonym przypadku policjant posiadał służbową broń palną, przez co narażał na niebezpieczeństwo życie i zdrowie innych osób.

W innym wyroku przyjęto, że inkryminowane jest spożywanie alkoholu w obiektach i na terenach zajmowanych przez Policję niezależnie od tego, czy sprawca w chwili popełnienia takiego deliktu dyscyplinarnego jest w służbie czy też nie (wyrok NSA z 24 września 2009 r.). Taka ocena wymienionego czynu wynika wprost z art. 132 ust. 3 pkt 6 ustawy o Policji. Komendant Główny Policji uznał wydalenie ze służby, w okolicznościach danej sprawy, za rozstrzygnięcie prawidłowe, uwzględniające przesłanki z art. 134h ust. 1 ustawy o Policji, 
tj. okoliczności popełnienia przewinienia dyscyplinarnego, jego skutki, w tym następstwa dla służby, pobudki działania, zachowanie obwinionego przed popełnieniem przewinienia dyscyplinarnego i po jego popełnieniu oraz dotychczasowy przebieg służby (tamże).

Kara dyscyplinarna wydalenia ze służby w Policji oraz kara zakazu prowadzenia pojazdów mechanicznych przez okres 12 miesięcy zostały nałożone na policjanta za kierowanie samochodem w stanie nietrzeźwości (wyrok NSA z 4 listopada 2004 r.). Krytycznie oceniono takie zachowanie funkcjonariusza, który - również poza służbą - prowadził pojazd mechaniczny w stanie po użyciu alkoholu. Naczelny Sąd Administracyjny w wyroku z 16 czerwca 2011 r. wskazał, że w sytuacji, gdy funkcjonariusz Policji podejmuje decyzję o prowadzeniu pojazdu mechanicznego po użyciu alkoholu, trudno uznać inny środek karny niż kara wydalenia ze służby za bardziej adekwatny do wagi przewinienia dyscyplinarnego. Kara wydalenia jest bowiem równoznaczna z sytuacją, gdy waga popełnionego przewinienia nie pozwala na dalsze pełnienie służby. „Nie ma znaczenia prawnego to, czy obwiniony dobrowolnie poddał się czynnościom kontrolnym, przyznał do winy, złożył wyjaśnienia czy wyraził skruchę, bowiem ciężar przewinienia dyscyplinarnego determinuje wymiar kary [...]. Prowadzenie pojazdu po użyciu alkoholu nie może być kwalifikowane przez organ dyscyplinarny jedynie jako naganne. Istotne są bowiem stan po użyciu alkoholu i prowadzenie pojazdu w takim stanie. Zachowanie takie świadczy o wyjątkowej nieodpowiedzialności osoby, która po użyciu alkoholu decyduje się na prowadzenie pojazdu. Ma to tym większe znaczenie, że dotyczy funkcjonariusza Policji, a więc osoby, dla której idea służby dla społeczeństwa winna przyświecać w każdej sytuacji, niezależnie od tego, czy policjant w danym momencie pełni służbę czy też pozostaje poza nią" (tamże). We wskazanym wyroku przyjęto, że z uwagi na cel i zadania Policji nie tylko zasady etyczne dyskwalifikują zachowanie takie jako policjanta, ale także jego postawa wobec zadań, jakie ustawodawca nałożył na funkcjonariuszy Policji, wobec czego nawet nienaganne opinie nie mogą wpłynąć na zmianę stanowiska organu Policji na temat wymierzonej kary wydalenia (tamże).

Wśród przykładów zachowań stanowiących naruszenie etyki zawodowej, niestanowiących naruszenia dyscypliny służbowej, podać można przykład działania funkcjonariusza, który poza służbą po spożyciu alkoholu zachowywał się w sposób wulgarny. Sąd stwierdził, że: ,ppolicjant z wieloletnim stażem i starszy stopniem powinien dawać przykład poprawnego zachowania, a podczas interwencji nie naruszać porządku prawnego" (wyrok NSA z 31 stycznia 2014 r.). W tym przypadku policjant, zamiast budować zaufanie do Policji, swoją postawą ukazał tę formację w negatywny sposób, naruszając tym samym jej autorytet ${ }^{9}$. Takie zachowanie - zarówno w ocenie organów dyscyplinarnych, jak i sądów

${ }^{9} \mathrm{~W}$ tym przypadku chodziło o negatywne zachowanie się policjanta wobec pracowników izby wytrzeźwień, którzy wiedzieli, jaką funkcję on pełni. 
administracyjnych - uznać należy za bulwersujące i naganne. Wobec powyższego nawet wcześniejsza wieloletnia wzorowa służba nie mogła mieć wpływu na złagodzenie wymiaru kary dyscyplinarnej.

Wydalony ze służby został także funkcjonariusz, który „w czasie wolnym od służby, w stanie wskazującym na spożycie alkoholu, będąc zobowiązanym do dbania o społeczny wizerunek Policji jako formacji, w której służy, i podejmowania działań służących budowaniu zaufania do niej oraz do przestrzegania w stosunku do innych policjantów zasad poprawnego zachowania, poszanowania godności, nie przestrzegał zasad etyki zawodowej policjanta w ten sposób, że zakłócał ciszę nocną, był wulgarny, agresywny i pogardliwy wobec interweniujących policjantów, używał słów powszechnie uznanych za obelżywe, groził funkcjonariuszom wydaleniem ze służby, pomówił ich o kradzież telefonu komórkowego, usiłował zbiec z izby wytrzeźwień, nie podporządkował się wydanym na podstawie prawa poleceniom policjantów, a w trakcie przyjmowania do izby wytrzeźwień stwarzał zagrożenie dla własnego życia i zdrowia, co spowodowało konieczność zastosowania wobec niego chwytów obezwładniających i pasów bezpieczeństwa" (wyrok NSA z 31 stycznia 2014 r.). Istotne jest, że dla samego faktu popełnienia opisywanego przewinienia dyscyplinarnego nie ma znaczenia, czy policjant popełniając dany czyn był na służbie.

Analiza dorobku judykatury dowodzi, że przypadki popełniania przewinień dyscyplinarnych przez funkcjonariuszy po spożyciu alkoholu są niedopuszczal$\mathrm{n}^{10}$. Zachowania takie należy uznać za szczególnie naganne $\mathrm{z}$ uwagi na fakt, że każda czynność służbowa podejmowana przez policjanta wymaga nie tylko wiedzy zawodowej, lecz przede wszystkim świadomej, niczym nieograniczonej (trzeźwej) reakcji policjanta, zaś stan nietrzeźwości wyklucza świadome działanie funkcjonariusza.

Odrębną grupę stanowią przewinienia dyscyplinarne popełnione przez funkcjonariuszy Policji w stanie trzeźwości. Należy się zastanowić nad charakterem czynów popełnionych przez trzeźwych funkcjonariuszy, które uzasadniają zastosowanie tej kary. Nie ulega wątpliwości, że kara dyscyplinarna wydalenia ze służby - co do zasady - znajduje uzasadnienie w sytuacjach, gdy czyn policjanta wypełnia znamiona przestępstwa. Wśród tego rodzaju przewinień warto zwrócić uwagę na, wprowadzone przez samą Policję, kategorie przewinień stanowiących równocześnie „kategorie przestępstw”" wań dyscyplinarnych przeciwko funkcjonariuszom:

\footnotetext{
${ }^{10}$ Naczelny Sąd Administracyjny w wyroku z 31.1.2014 r. (I OSK 2687/12, LEX nr 1449900) stwierdził nawet, że sytuacje, gdy funkcjonariusz, który odwozi do izby wytrzeźwień osoby zakłócające porządek publiczny, sam trafia do tej izby, są niedopuszczalne. Przy czym dla oceny tego typu czynu pod względem odpowiedzialności dyscyplinarnej nie ma znaczenia, czy policjant działał na służbie czy po służbie.

${ }^{11}$ Nomenklatura wprowadzona przez Policję w Zestawieniu spraw karnych przeciwko policjantom o czyny wyczerpujące jednocześnie znamiona przewinień dyscyplinarnych.
} 
a) czyny związane z przyjmowaniem korzyści majątkowych przez funkcjonariuszy;

b) wykorzystanie stanowiska służbowego;

c) przywłaszczenia, kradzieże, rozboje;

d) pobicia oraz naruszenia innych dóbr osobistych ${ }^{12}$.

Jedną z grup zachowań, których następstwem było wydalenie funkcjonariusza ze służby, są czyny związane z przyjmowaniem korzyści majątkowej. Już jednokrotne przyjęcie takiej korzyści może prowadzić do zastosowania omawianej kary (wyrok NSA z 23 kwietnia 2014 r.). Zdarza się również, że funkcjonariusze wielokrotnie dopuszczają się czynów zabronionych z powyższej kategorii, jak na przykład policjant, który: „działając w warunkach przestępstwa ciagłego, wspólnie i w porozumieniu z innymi funkcjonariuszami Policji, przyjął od osoby trzeciej co najmniej siedem razy korzyść majątkową w zamian za odstapienie od czynności zatrzymania" (wyrok WSA w Warszawie z 5 marca 2013 r.).

Następny rodzaj zachowania prowadzącego do zastosowania kary wydalenia ze służby to wykorzystanie stanowiska służbowego, które może polegać na przekazaniu przez policjanta informacji o planowanych akcjach osobom zamieszanym w działalność przestępczą. Można tu podać przykład funkcjonariusza, który „przy użyciu służbowych metod w postaci wiedzy o planowanych akcjach wymierzonych przeciwko przestępczości związanej z nielegalnym obrotem wyrobami alkoholowymi oraz tytoniowymi z obszaru wolnocłowego oraz na temat właścicieli pojazdów, przekazał osobom zaangażowanym w działalność przemytniczą oraz na ich prośbę zlecił prowadzenie kontroli drogowej pojazdu" (wyrok NSA z 17 lipca 2007 r.).

Negatywnie jest również oceniane zaangażowanie policjanta w takie czyny karalne, jak: przywłaszczenia, kradzieże, rozboje. Przykładowo w sytuacji, gdy „funkcjonariusz pełniąc służbę patrolową, przekroczył swoje uprawnienia i działał na szkodę interesu publicznego w ten sposób, że wspólnie i w porozumieniu z innymi nieustalonymi osobami wziął udział w dokonaniu kradzieży z włamaniem do samochodu" (wyrok WSA w Warszawie z 21 czerwca 2010 r.; wyrok NSA z 15 marca 2011 r.). Podkreślić w tym miejscu należy, że postępowanie dyscyplinarne i kara dyscyplinarna to nie jedyne postępowanie i kara, jakie mogą zostać zastosowane wobec funkcjonariusza, którego czyny wypełniają znamiona wykroczenia lub przestępstwa. Zrozumiałe jest w pełni, że wydalenie ze służby powinno nastapić w przypadku popełnienia przez policjanta przestępstw, w tym szczególnie poważnych, co nie zmienia faktu, że czyny te mogą stać się również podstawą postępowania karnego. Naczelny Sąd Administracyjny w wyroku z 15 marca 2011 r. analizując stan faktyczny dotyczący kradzieży z włamaniem, odniósł się do sytuacji, gdy toczy się

${ }^{12}$ Materiały uzyskane na potrzeby badań naukowych z Komendy Głównej Policji: Zestawienie spraw karnych przeciwko policjantom o czyny wyczerpujące jednocześnie znamiona przewinień dyscyplinarnych. 
równocześnie postępowanie karne i dyscyplinarne. Co do zasady postępowania te są postępowaniami odrębnymi, niezależnymi, prowadzonymi w różnych trybach. W wymienionym wyroku dostrzeżono, że „w sytuacji, w której toczyło się równolegle postępowanie karne i postępowanie dyscyplinarne przeciwko funkcjonariuszowi - w wypadku jednoczesności i podmiotowo-przedmiotowej tożsamości tych postępowań - zagadnieniem fundamentalnym jest to, by nie doszło in concreto do zapadnięcia $\mathrm{w}$ takiej sytuacji odmiennych orzeczeń w postępowaniu dyscyplinarnym i w postępowaniu karnym" (tamże). Uniewinnienie w postępowaniu karnym oznacza możliwość prowadzenia postępowania dyscyplinarnego przeciwko temu funkcjonariuszowi jedynie, gdy postępowanie dyscyplinarne dotyczy przewinienia dyscyplinarnego, które nie wyczerpuje znamion przestępstwa (Uzasadnienie uchwały SN (7) z 28 września 2006 r.). Mając na uwadze pozycję ustrojową sądów, nie można uznać, by prawomocny wyrok uniewinniający sądu karnego nie miał wpływu na prawną kwalifikację decyzji dyscyplinarnej, nawet jeśli stała się ostateczna, zanim wyrok uniewinniający stał się ostateczny. Dopiero jednak wzruszenie ostatecznej decyzji dyscyplinarnej stanie się przesłanką do zweryfikowania zgodności z prawem ostatecznej decyzji o zwolnieniu funkcjonariusza ze służby w trybie art. 41 ust. 1 pkt 3 ustawy o Policji (wyrok NSA z 15 marca 2011 r.). Skoro prawodawca dopuścił, by ten sam czyn funkcjonariusza Policji był podstawą ponoszenia odpowiedzialności dyscyplinarnej, niezależnie od odpowiedzialności karnej (art. 132 ustawy o Policji), to musiał również uwzględnić możliwość zaistnienia sytuacji, w której treść wcześniejszego orzeczenia (z reguły dyscyplinarnego) kształtować się będzie odmiennie w kwestii orzekania o winie od późniejszego (co do zasady) - przed sądem powszechnym ${ }^{13}$. Ustawodawca przewidział jednak środki mające na celu ograniczenie skutków wskazanej kolizji (w wyroku NSA z 15.3.2011 r., I OSK 1588/10, LEX nr 1079704 wskazano na mechanizmy opisane w art. 42 ust. 1 i 7 ustawy o Policji; art. 125 ust. 2 ustawy o Policji; art. 135r ust. 1 i 5 ustawy o Policji).

Postępowanie dyscyplinarne zakończone karą wydalenia ze służby dotyczyło też funkcjonariusza Policji biorącego udział w pobiciu: „Uczestniczył w zdarzeniu polegającym na stosowaniu agresji, wskutek czego nastąpiły u pokrzywdzonego obrażenia ciała [...] poprzez uderzenie pokrzywdzonego pięścią w twarz, które to obrażenia ciała spowodowały naruszenie czynności narządów ciała na okres poniżej 7 dni" (wyrok WSA w Warszawie z 4 listopada 2004 r.).

W judykaturze jedynie incydentalnie znajduje się przykłady stanów faktycznych, w których za zachowania policjantów niestanowiące przestępstw (bądź co

${ }^{13}$ Stanowisko Naczelnego Sądu Administracyjnego odnośnie do odmienności postępowania dyscyplinarnego od postępowania karnego wyrażono również w wyroku z dnia 17.7.2007 r. (I OSK 822/06), w którym NSA wskazał, że w postępowaniu dyscyplinarnym nie obowiązuje zasada domniemania niewinności i rozpatrywanie niedających się wyjaśnić wątpliwości na korzyść obwinionego. Dopuszczalne są sytuacje, w których organ dyscyplinarny wyda inne rozstrzygnięcie w zakresie winy funkcjonariusza niż sąd karny (zob. też wyrok NSA z 15.4.2003 r., II SA 452/02, LEX nr 142331). 
do których nie toczyło się postępowanie karne) dokonane w stanie trzeźwości wymierzono funkcjonariuszom karę wydalenia ze służby w Policji.

Można podać chociażby przypadek funkcjonariusza, który nie stawił się do służby oraz nie usprawiedliwił swoich nieobecności (nie przedstawił bezpośredniemu przełożonemu zaświadczenia lekarskiego o czasowej niezdolności do służby w tym okresie z powodu choroby), czym naruszył dyscyplinę służbową. Przy uwzględnieniu, że powyższe zachowanie miało miejsce przed zatarciem skazania poprzedniej kary dyscyplinarnej, policjantowi wymierzono karę dyscyplinarną wydalenia ze służby (wyrok WSA w Krakowie z dnia 26 listopada 2008 r.). W przedstawionych wyżej okolicznościach na rodzaj zastosowanej kary dyscyplinarnej miał jednak znaczący wpływ fakt, że nie nastapiło zatarcie skazania za poprzednie przewinienie dyscyplinarne, nie zaś sam charakter przewinienia.

W przywołanych przypadkach daje się zauważyć pewna prawidłowość. Przewinienia występują najczęściej wśród dwóch grup funkcjonariuszy: najmłodszych stażem i najstarszych stażem. W tym drugim przypadku przyjmuje się, że wynika to zwłaszcza z tzw. wypalenia zawodowego ${ }^{14}$.

Podane przykłady przewinień dyscyplinarnych skutkujących wydaleniem ze służby stanowią jedynie niewielki wycinek prowadzonych postępowań dyscyplinarnych, także tych zakończonych najbardziej dotkliwą, omawianą karą. W poniższej tabeli przedstawiam dane statystyczne dotyczące kar dyscyplinarnych wymierzonych funkcjonariuszom, opublikowane przez Policję.

Tabela

\begin{tabular}{|c|c|c|c|c|c|c|c|c|c|c|c|}
\hline Rok & 1'93 & 1'94 & 1'95 & 1'96 & 1'97 & 1'98 & 1'99 & $2^{\prime} 00$ & $2^{\prime} 01$ & 2’02 & 2'03 \\
\hline $\begin{array}{l}\text { Wymierzono } \\
\text { kar ogółem }\end{array}$ & 4850 & 4753 & 4661 & 4891 & 4757 & 2547 & 2244 & 2838 & 2884 & 2556 & 1796 \\
\hline $\begin{array}{l}\text { W tym } \\
\text { wydalenia ze } \\
\text { służby }\end{array}$ & 493 & 408 & 259 & 336 & 288 & 172 & 197 & 295 & 284 & 308 & 204 \\
\hline Rok & 2’04 & $2^{\prime} 05$ & 2’06 & $2^{\prime} 07$ & $2^{\prime} 08$ & 2’09 & $2 ' 10$ & 2'11 & $2^{\prime} 12$ & $2^{\prime} 13$ & $2^{\prime} 14$ \\
\hline $\begin{array}{l}\text { Wymierzono } \\
\text { kar ogółem }\end{array}$ & 1682 & 1331 & 940 & 772 & 625 & 602 & 586 & 533 & 534 & 607 & 731 \\
\hline $\begin{array}{l}\text { W tym } \\
\text { wydalenia ze } \\
\text { służby }\end{array}$ & 103 & 78 & 81 & 77 & 27 & 29 & 24 & 26 & 18 & 39 & 35 \\
\hline
\end{tabular}

Źr ódło: http://statystyka.policja.pl/st/wybrane-statystyki/dyscyplina-w-policji/50845, Dyscyplina-w-Policji.html [dostęp 30.04.2016].

${ }^{14}$ Szerzej o wypaleniu zawodowym w Policji: Edward Wiszowaty (2011, 166-173). 
Z powyższych danych wynika, że liczba nakładanych kar wydalenia ze służby od 1993 r. systematycznie malała i z początkowego poziomu 493 przypadków w 1993 r. spadła do 35 przypadków w roku 2014. Na przestrzeni ponad dwudziestu pięciu lat obowiązywania ustawy o Policji zmianie uległa zarówno liczba wymierzonych kar dyscyplinarnych ogółem, jak i zastosowanych kar wydalenia ze służby. Można przyjać, że miało na to wpływ wiele różnych czynników, w tym m.in. związanych ze wzmożeniem w Policji działalności szkoleniowej mającej na celu zapoznanie funkcjonariuszy z przepisami prawa oraz odpowiedzialnością za ich naruszenie. Nie bez znaczenia mogły być również zmiany przepisów w zakresie postępowania kwalifikacyjnego i procedury rekrutacji do Policji poprzez wieloetapowy proces selekcji mające zapewnić odpowiedni dobór osób do służby w tej formacji.

Nie ulega wątpliwości, że tendencja spadkowa w zakresie liczby przewinień dyscyplinarnych jest zjawiskiem ze wszech miar pożądanym. Za niepokojący winien więc zostać uznany przyrost liczby wymierzonych kar, jak i samych wydaleń ze służby odnotowywany w ostatnich kilku latach.

\section{KONSEKWENCJE WYDALENIA ZE SLUŻBY}

Konsekwencje wydalenia ze służby mogą być różnej natury. Niektóre z nich są następstwem środków zastosowanych wobec funkcjonariuszy w związku z wszczęciem postępowania dyscyplinarnego. Przykładowo w art. 39 ust. 2 ustawy o Policji dopuszczono fakultatywne zawieszenie w czynnościach służbowych policjanta już w razie wszczęcia przeciwko niemu postępowania dyscyplinarnego, w przypadku gdy jest to celowe $\mathrm{z}$ uwagi na dobro postępowania lub dobro służby - na czas nie dłuższy niż 3 miesiące. Zawieszenie w czynnościach służbowych jest równoznaczne z zawieszeniem płatności - 50\% ostatnio należnego uposażenia (art. 124 ust. 1 ustawy o Policji) - od najbliższego terminu (po zawieszeniu w czynnościach służbowych). W przypadku ukarania policjanta wydaleniem ze służby zostaje on pozbawiony części uposażenia oraz obligatoryjnych podwyżek wprowadzonych w okresie jego zawieszenia w czynnościach służbowych (art. 124 ust. 2 ustawy o Policji).

Wymierzenie kary wydalenia ze służby wiąże się także z innymi obligatoryjnymi negatywnymi skutkami finansowymi. Policjantom oprócz wynagrodzenia za pracę przysługuje - zgodnie z przepisami rozporządzenia Ministra Spraw Wewnętrznych i Administracji z 6.12.2001 r. w sprawie szczegółowych zasad otrzymywania i wysokości uposażenia zasadniczego policjantów, dodatków do uposażenia oraz ustalania wysługi lat, od której jest uzależniony wzrost uposażenia zasadniczego (Dz. U. Nr 152, poz. 1732 ze zm., dalej: rozporządzenie) - dodatek służbowy lub funkcyjny. Skutki wydalenia ze służby w zakresie dodatku funkcyjnego i służbowego są odmienne. Ten pierwszy jest bowiem obligatoryjnie 
obniżany ( 88 ust. 8 pkt 1 rozporządzenia), drugi zaś zostaje cofnięty ( 9 ust. 6 pkt 1 rozporządzenia). Kolejną konsekwencją finansową, wskazaną w art. 114 ust. 3 ustawy o Policji, jest pozbawienie policjanta wydalonego ze służby (w trybie art. 41 ust. 1 pkt 3 ustawy o Policji) - 50\% odprawy. Takiemu funkcjonariuszowi nie przysługuje również nagroda roczna (zob. art. 110 ust. 7 pkt 3 ustawy o Policji).

Wydalenie ze służby - jako że oznacza kres możliwości stosowania do danej osoby przepisów ustawy o Policji (wyrok WSA w Olsztynie z 26 lutego 2004 r.) - wiąże się nadto z utratą przywilejów socjalnych policjantów w służbie stałej, czyli w szczególności: prawa do lokalu mieszkalnego - przewidzianego w 88 ust. 1 ustawy o Policji; prawa do równoważnika pieniężnego za remont zajmowanego lokalu mieszkalnego czy prawa do równoważnika pieniężnego, jeżeli policjant lub członkowie jego rodziny nie posiadają lokalu mieszkalnego w miejscu pełnienia służby lub w miejscowości pobliskiej - przewidzianego w art. 92 ust. 1 ustawy o Policji.

Inną szczególnie dolegliwą konsekwencją wydalenia ze służby w Policji jest utrata prawa wliczenia okresu służby do okresu zatrudnienia. Zgodnie z art. 80 ust. 1 ustawy o Policji: „Policjantowi, który podjął pracę w ciagu roku od dnia zwolnienia ze służby, a jeżeli pełnił służbę przygotowawczą - w ciągu 3 miesięcy od tego dnia, okres służby wlicza się do okresu zatrudnienia w zakresie wszelkich uprawnień wynikających z prawa pracy". Artykuł 80 ust. 4 stanowi jednak, że uprawnienie to nie przysługuje policjantom zwolnionym ze służby w razie skazania prawomocnym wyrokiem sądu lub ukarania karą dyscyplinarną wydalenia ze służby.

Powyższe negatywne konsekwencje związane są jedynie z karą dyscyplinarną wydalenia ze służby. Nie występują one w przypadku nałożenia na policjantów innego rodzaju kary dyscyplinarnej.

Podkreślenia wymaga, że z treści art. 42 ust. 1 ustawy o Policji wynika, iż jedynie uchylenie lub stwierdzenie nieważności decyzji o zwolnieniu ze służby (w tym z uwagi na zastosowanie kary dyscyplinarnej wydalenia ze służby) z powodu jej wadliwości stanowi podstawę przywrócenia do służby na stanowisko równorzędne. Nie ma innych możliwości przywrócenia do służby byłego policjanta wydalonego ze służby. W doktrynie dostrzegalna jest rozbieżność poglądów w kwestii terminowego charakteru wydalenia ze służby. Niektórzy przyjmują, że wydalenie ze służby w Policji nie uniemożliwia ponownego przyjęcia do tej formacji (Maj 2008, 55). Należałoby się jednak zastanowić, czy były funkcjonariusz zwolniony w związku $z$ orzeczeniem wobec niego kary dyscyplinarnej wydalenia ze służby będzie w ogóle spełniał wymagania z art. 25 ustawy o Policji, w tym w szczególności w zakresie: nieposzlakowanej opinii czy zdolności fizycznej i psychicznej do służby w formacjach uzbrojonych, podlegających szczególnej dyscyplinie służbowej, a zwłaszcza gotowości do podporządkowania się tej dyscyplinie. Dlatego też zgodzić się należy ze stanowiskiem wyrażonym m.in. przez W. Kotowskiego, że funkcjonariusz wydalony ze służby w praktyce utraci możliwość ponownego powołania do służby czy chociażby uzyskania pracy w instytucji ochrony prawnej (Kotowski, LEX 2012). Podobną, choć bardziej stanowczą opinię wysunął R. Giętkowski, uznając, 
że z przepisów ustawy o Policji wynika dożywotniość wydalenia ze służby, a zatem brak możliwości ponownego ubiegania się o przyjęcie do służby po upływie jakiegokolwiek czasu (Giętkowski 2013, 278). Były funkcjonariusz może mieć także znaczne trudności w uzyskaniu innej pracy, zwłaszcza gdy wymaga ona - podobnie jak praca w Policji - przestrzegania dyscypliny służbowej, np. praca w innego rodzaju formacjach ochronnych.

\section{POSUMOWANIE}

Omówione wyżej wydalenie ze służby w Policji jest najbardziej dolegliwą z kar dyscyplinarnych, jakie zostały przewidziane w przepisach ustawy o Policji. Kara ta pociaga za sobą wiele negatywnych dla ukaranego konsekwencji. Przede wszystkim traci on status funkcjonariusza Policji. Utrudnia mu również znalezienie innej pracy, z uwagi na fakt, że niezgodne z przepisami postępowanie funkcjonariuszy publicznych jest szczególnie negatywnie oceniane przez społeczeństwo. Naczelny Sąd Administracyjny niejednokrotnie podnosił, że na zaufaniu społecznym opiera się m.in. status Policji (m.in. wyrok NSA z 16 grudnia 2010 r.). Nie dziwi więc fakt, że zachowania funkcjonariuszy zasługujące na szczególne potępienie, równoznaczne z utratą ich autorytetu, mogące przekładać się na niekorzystny obraz Policji, skutkują wydaleniem ze służby. Mając na uwadze nie tylko represyjną, ale i prewencyjną funkcję tej kary, uznać ją należy za element niezbędny do prawidłowego funkcjonowania tej formacji.

Ze statystyk policyjnych wynika, że na przestrzeni ostatnich ponad dwudziestu lat częstotliwość stosowania wskazanej kary w postępowaniach dyscyplinarnych uległa znacznemu spadkowi, co może świadczyć o wzroście poprawności zachowań policjantów.

Niemniej fakt występowania przypadków zastosowania wskazanego rodzaju kary dyscyplinarnej w stosunku do funkcjonariuszy popełniających przewinienia dyscyplinarne wymaga nakreślenia pewnych prawidłowości w praktyce orzeczniczej w tym zakresie. Nie ulega wątpliwości, że najczęściej kara ta jest orzekana w przypadkach, gdy czyn stanowiący przewinienie dyscyplinarne wypełnia równocześnie znamiona przestępstwa, choć za popełnienie czynów niestanowiących przestępstw (bądź co do których nie toczyło się postępowanie karne) policjanci również mogą być karani wydaleniem ze służby. Często ma to miejsce, gdy zachodzą przesłanki zaostrzenia wymiaru kary, jak w szczególności działania w stanie po użyciu alkoholu. Przy czym ze względu na charakter służby w Policji, już samo stawienie się do służby w takim stanie może uzasadniać wydalenie funkcjonariusza z Policji. Odnotowywane są pojedyncze przypadki przewinień dyscyplinarnych popełnianych w stanie trzeźwości, niestanowiących przestępstw (bądź co do których nie toczyło się postępowanie karne), za które wymierzono karę wydalenia ze służby, jednak należy je traktować jako sytuacje wyjątkowe. 
W praktyce orzeczniczej, wśród względów decydujących o zastosowaniu kary wydalenia ze służby w Policji warto zwrócić uwagę przede wszystkim na: dbanie o społeczny wizerunek i zaufanie do Policji, którymi organy dyscyplinarne i sądy administracyjne wielokrotnie uzasadniały zastosowanie tej kary. Wszelkie czyny funkcjonariuszy świadczące o ich wyjątkowej nieodpowiedzialności naruszają autorytet Policji, co - jak wynika z dokonanej analizy orzecznictwa - jawi się jako niedopuszczalne. Podkreślenia wymaga, że policjant jest i zawsze będzie oceniany nie tylko poprzez pryzmat posiadanych kwalifikacji zawodowych i osiagnniętych wyników, ale również postawy, stosunku do obowiązujących przepisów pragmatyki służbowej. Jeżeli więc w okolicznościach danej sprawy zostanie wykazane, że obwiniony umyślnie przedłożył działanie z niskich pobudek nad obowiązujące go zasady i normy prawne, to organ może zasadnie uznać, że obwiniony nie daje gwarancji podporządkowania się rygorom dyscypliny służbowej.

Policja jest szczególną formacją służącą ludziom i wspólnocie. Przeciwdziała ona naruszeniom prawa. Ważne jest zatem, by jej funkcjonariusze działali zawsze na podstawie i w granicach unormowań prawnych. Łamanie prawa przez tych, którzy zobowiązani są do jego strzeżenia, musi pociagać za sobą ich wymierną odpowiedzialność. Sprzyjać temu powinny między innymi dobre regulacje prawne.

Wydawać by się mogło, że regulacja ustawowa jest w przypadku tej kary zbyt mało szczegółowa. Trudno w tym przypadku sformułować katalog zamknięty przewinień, których popełnienie stanowiłoby przesłankę wydalenia ze służby - obecna regulacja jawi się jako uzasadniona.

Ważne jest jednak, by unormowania te były faktycznie stosowane z pełną surowością wobec tych, którzy swoim bezprawnym zachowaniem wypełniają znamiona czynu objętego tą karą. Tylko jej nieuchronność sprawi, że Policja pełnić będzie właściwie przypisaną jej misję społeczną, ciesząc się zasłużonym autorytetem tych, których zgodnie z prawem ma wspierać i chronić.

\section{BIBLIOGRAFIA}

Baj, Dariusz, Dariusz Bober. 2013. Odpowiedzialność dyscyplinarna policjanta. Legionowo: Centrum Szkolenia Policji.

Czebotar, Łukasz, Zuzanna Gądzik, Aneta Łyżwa, Aneta Michałek, Anna Świerczewska-Gąsiorowska, Mirosław Tokarski. 2015. Ustawa o Policji. Komentarz. Warszawa: Wolters Kluwer.

Giętkowski, Radosław. 2013. Odpowiedzialność dyscyplinarna w prawie polskim. Gdańsk: Wydawnictwo Uniwersytetu Gdańskiego.

Kotowski, Wojciech. 2012. Ustawa o Policji. Komentarz. LEX.

Kuczyński, Tadeusz. 2012. „Odpowiedzialność funkcjonariuszy służb zmilitaryzowanych za przewinienia dyscyplinarne mniejszej wagi”. Zeszyty Naukowe Sadownictwa Administracyjnego 6.

Maj, Sebastian. 2008. Postępowanie dyscyplinarne w stużbach mundurowych. Warszawa: LexisNexis. 
Opaliński, Bartłomiej, Maciej Rogalski, Przemysław Szustakiewicz. 2015. Ustawa o Policji. Komentarz. Warszawa: C.H. Beck.

Wiszowaty, Edward. 2011. Etyka Policji. Między prawem, moralnościq i skutecznościq. Warszawa: Oficyna Wydawnicza ŁośGraf.

\section{Orzecznictwo}

Uchwała SN (7) z 28.9.2006 r., I KZP 8/06, OSNKW 10/06/87.

Ustawa z dnia 6 kwietnia 1990 r. o Policji (tekst jedn. Dz. U. 2015, poz. 355 ze zm.).

Ustawa z 29.10.2003 r. zmieniająca ustawę o Policji (Dz. U. Nr 192, poz. 1873).

Wyrok TK z 2.9.2008 r., K. 35/06, OTK-A 2008/7/120.

Wyrok NSA (do 31.12.2003 r.) w Warszawie z dnia 25.10.1999 r., II SA 1610/99, LEX nr 47421.

Wyrok NSA z 15.4.2003 r., II SA 452/02, LEX nr 142331.

Wyrok NSA z 4.11.2004 r., II SA 1924/03, LEX nr 158431.

Wyrok NSA z 19.1.2007 r., I OSK 637/06, LEX nr 320611.

Wyrok NSA z 24.9.2009 r., I OSK 702/09, LEX nr 595481.

Wyrok NSA z 16.12.2010 r., I OSK962/10, LEX 745390.

Wyrok NSA z 15.3.2011 r., I OSK 1588/10, LEX nr 1079704.

Wyrok NSA z 16.11.2011 r., I OSK 209/11, LEX nr 1082691.

Wyrok NSA z 31.1.2014 r., I OSK 2687/12, LEX nr 1449900.

Wyrok NSA z 31.1.2014 r., I OSK 2687/12, LEX nr 1449900.

Wyrok NSA z 23.4.2014 r., I OSK 709/13, LEX nr 1574682.

Wyrok WSA w Olsztynie z 26.2.2004 r., I SA 1546/03, LEX nr 708179.

Wyrok WSA w Olsztynie z 16.3.2004 r., II SA 1425/02, LEX nr 697511.

Wyrok WSA w Warszawie z 4.11.2004 r., II SA 3880/03, LEX nr 718244.

Wyrok WSA w Warszawie z 17.1.2006 r., II SA/Wa 1755/05, LEX nr 194440.

Wyrok WSA w Warszawie z 26.2.2007 r., II SA/Wa 2354/06, LEX nr 318265.

Wyrok NSA z 17.7. 2007 r., I OSK 822/06, LEX nr 447262.

Wyrok WSA w Krakowie z 26.11.2008 r., III SA/Kr 803/08, LEX nr 541458.

Wyrok WSA w Warszawie z 21.6.2010 r., II SA/Wa 273/10, LEX nr 643823.

Wyrok WSA we Wrocławiu z 27.10.2010 r., IV SA/Wr 287/10, LEX nr 759127.

Wyrok WSA w Warszawie z 7.1.2013 r., II SA/Wa 1975/12, LEX nr 1325991.

Wyrok WSA w Krakowie z 22.1.2013 r., III SA/Kr 452/12, LEX nr 1274770.

Wyrok WSA w Warszawie z 5.3.2013 r., II SA/Wa 2300/12, LEX nr 1321485.

Wyrok WSA w Poznaniu z 9.10.2013 r., II SA/Po 708/13, LEX nr 1390266.

Wyrok WSA w Łodzi z 10.2.2015 r., III SA/Łd 1038/14, LEX nr 1767116.

Zarządzenie nr 805 Komendanta Głównego Policji z 31.12.2003 r. (Dz. Urz. KGP 2004, Nr 1, poz. 3).

\section{Monika Kapusta}

\section{AN INSTITUTION OF DISMISSAL FROM THE POLICE SERVICE AS A CONSEQUENCE OF DISCIPLINARY PENALTY - SELECTED ISSUES}

\footnotetext{
Abstract. The purpose of this paper is to present the institution of dismissal from the police service. Deliberations presented in this paper have been limited to strictly selected and described issues. This includes a description of the disciplinary proceedings in the police and essence of the dismissal from the police service. Moreover, there are some examples of behavior that justifies the use of this penalty. Attention is also paid to the consequences of dismissal from the police service.
} 
Keywords: dismissal from the police service, disciplinary penalty, disciplinary proceedings, disciplinary offence, consequences of the dismissal from the police service. 